\title{
HtrA chaperone activity contributes to host cell binding in Campylobacter jejuni
}

Kristoffer T Bæk, Christina S Vegge and Lone Brøndsted*

\begin{abstract}
Background: Acute gastroenteritis caused by the food-borne pathogen Campylobacter jejuni is associated with attachment of bacteria to the intestinal epithelium and subsequent invasion of epithelial cells. In C. jejuni, the periplasmic protein HtrA is required for efficient binding to epithelial cells. HtrA has both protease and chaperone activity, and is important for virulence of several bacterial pathogens.

Results: The aim of this study was to determine the role of the dual activities of $\mathrm{HtrA}$ in host cell interaction of $C$. jejuni by comparing an htrA mutant lacking protease activity, but retaining chaperone activity, with a $\triangle$ htrA mutant and the wild type strain. Binding of C. jejuni to both epithelial cells and macrophages was facilitated mainly by HtrA chaperone activity that may be involved in folding of outer membrane adhesins. In contrast, HtrA protease activity played only a minor role in interaction with host cells.
\end{abstract}

Conclusion: We show that HtrA protease and chaperone activities contribute differently to $C$. jejuni's interaction with mammalian host cells, with the chaperone activity playing the major role in host cell binding.

Keywords: HtrA, chaperone, protease, Campylobacter jejuni, INT-407, phagocytosis, virulence

\section{Background}

The enteric pathogen Campylobacter jejuni is a frequent cause of bacterial food-borne infections worldwide [1]. Acute gastroenteritis caused by C. jejuni is characterized by watery or bloody diarrhea, abdominal pain, fever, and malaise. While these symptoms typically last $3-7$ days, serious complications may follow such as the acute autoimmune disease Guillan Barré Syndrome, affecting the peripheral nervous system. To cause disease in humans, $C$. jejuni must penetrate the mucus layer of the gastrointestinal epithelium and interact with the underlying epithelial cells [2]. The importance of epithelial cell invasion in disease has been demonstrated in infected humans and animals [3,4], and is emphasized by studies showing that $C$. jejuni mutants attenuated for virulence in animal models are less capable of invading intestinal epithelial cells in vitro $[5,6]$. Upon invasion by C. jejuni, human epithelial cells respond by secreting cytokines, such as IL-8, which stimulate recruitment of inflammatory cells [2], including macrophages and

\footnotetext{
* Correspondence: lobr@life.ku.dk

* Correspondence: Iobr@life.ku.dk 4, DK-1870 Frederiksberg C, Denmark
}

(c) 2011 Bæk et al; licensee BioMed Central Ltd. This is an Open Access article distributed under the terms of the Creative Commons Biomed Central Attribution License (http://creativecommons.org/licenses/by/2.0), which permits unrestricted use, distribution, and reproduction in any medium, provided the original work is properly cited. dendritic cells that engulf and rapidly kill C. jejuni [7]. Adherence to epithelial cells is a prerequisite for invasion, and capsular polysaccharides, motility, and a number of surface associated proteins including CadF, CapA, JlpA and FlpA are required for efficient adherence of $C$. jejuni to epithelial cells [8-14]. Furthermore, metabolic processes in C. jejuni are also important for invasion of epithelial cells $[15,16]$.

HtrA is a highly conserved periplasmic protein that possesses both protease and chaperone activity $[17,18]$, and it has been demonstrated that HtrA is important for virulence of a number of bacterial pathogens such as Salmonella enterica serovar Typhimurium [19], Listeria monocytogenes [20], Klebsiella pneumonia [21] and Yersinia enterocolitica [22]. It is well established that HtrA is important for stress tolerance and survival of most bacteria, because HtrA degrades and prevents aggregation of periplasmic proteins that misfold during stress [23-25], however, only a few studies have investigated the individual role of the protease and chaperone activity of HtrA in virulence. Recently, it was shown that Salmonella Typhimurium requires both the HtrA protease and chaperone activity to grow in the liver and spleen of infected mice [26]. In contrast, only the chaperone 
activity of HtrA is important for spread of Shigella flexneri in cultured epithelial cells, possibly because HtrA is involved in the folding of the surface located virulence factor, IcsA $[27,28]$. This is consistent with a model for outer membrane biogenesis in non-pathogenic Escherichia coli proposing that the chaperone activity of HtrA ensures a safe transit of proteins across the periplasm and their assembly into the outer membrane [29]. Thus, even though HtrA is a conserved protein it is unpredictable whether the protease or chaperone activity is involved in virulence.

Several studies have suggested that HtrA is important for virulence of $C$. jejuni. Recently, an insect infection model was used to show that the outcome of a C. jejuni infection is affected by HtrA, as fewer Galleria mellonella larvae are killed by an htrA mutant than by the isogenic wild type strain [30]. In addition, we previously showed that attachment of C. jejuni to epithelial host cells is highly dependent on HtrA [31]. Furthermore, an htrA mutant was isolated from a $C$. jejuni transposon library screened for reduced invasion ability [16]. While several studies have revealed a role of HtrA in virulence of pathogenic bacteria, the question whether HtrA employs the chaperone or protease activity to promote bacterial virulence has received only limited attention. In the present study, we explore the role of HtrA in the virulence of $C$. jejuni by assessing the requirement for each HtrA activity in the interaction with host cells.

\section{Results and discussion}

Interaction of $C$. jejuni htrA mutants with epithelial cells and macrophages

HtrA of C. jejuni is a dual functional protein possessing both protease and chaperone activity [18]. To investigate which of these activities is important for the interaction of C. jejuni with human epithelial cells, we used a mutant (htrA S197A) encoding an HtrA protein with a single amino-acid change in the proteolytic site causing the protein to lack protease activity, but retain chaperone activity [18]. The adherence and invasion ability of the htrA S197A mutant was compared to the wild type as well as a $\triangle h t r A$ mutant in a gentamicin protection assay with cultured INT407 epithelial cells. Adherence of the htrA S197A mutant was reduced 3-fold compared to the wild type, while adherence of the $\Delta h t r A$ mutant was reduced 20-fold as reported previously (Figure 1A) [31]. Therefore, both chaperone and protease activity of HtrA are required for optimal adherence, but the chaperone activity alone greatly stimulates adherence. Likewise, invasion of INT407 cells by the htrA S197A mutant was reduced 7-fold compared to the wild type, while invasion by the $\triangle h t r A$ mutant was reduced at least 50-fold as previously reported (Figure 1B) [31]. Adherence is a prerequisite for invasion and the invasive

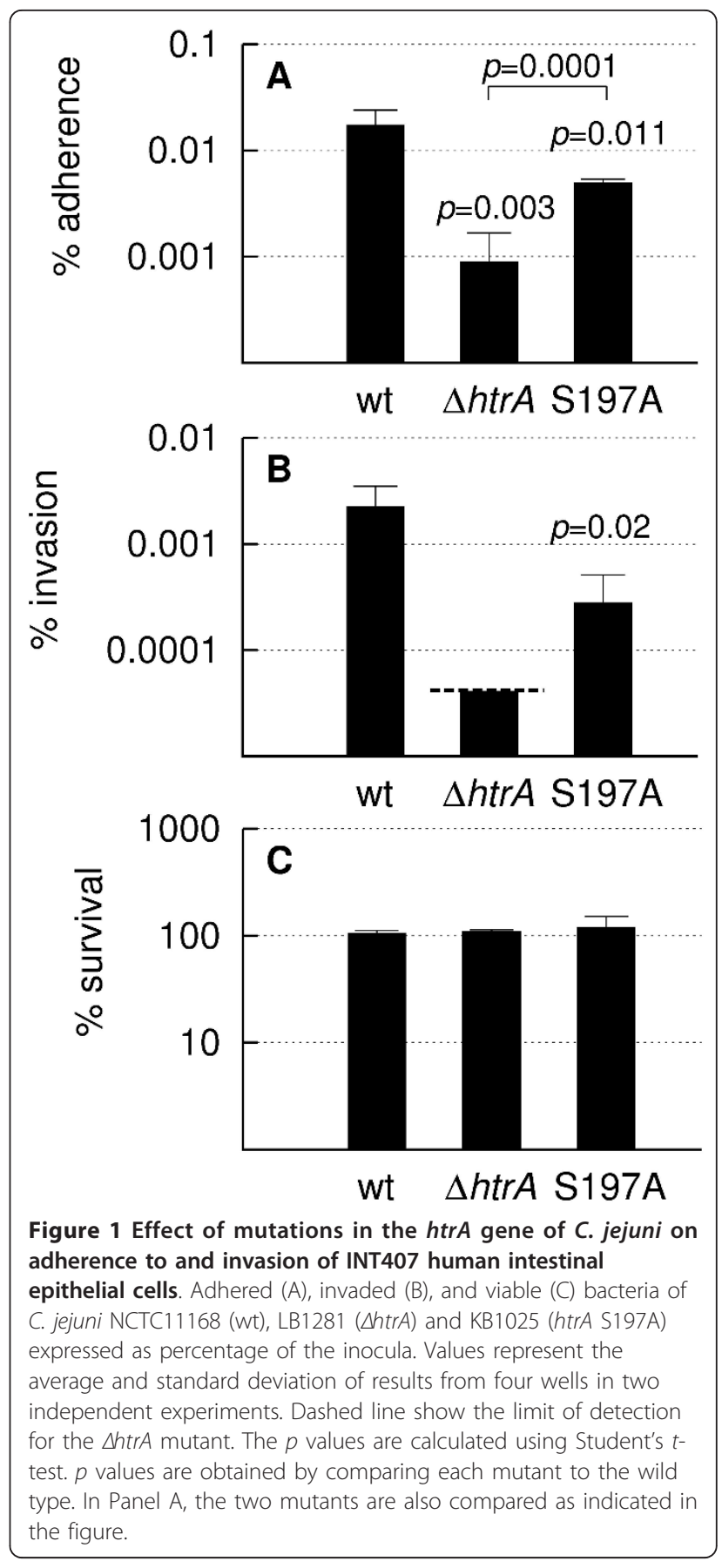

potential can therefore be expressed as the percentage of adherent bacteria that are internalized. This value thus normalizes for variable adherence, and reflects the capacity of already adhered bacteria to invade [32]. We found that the capacity to invade was $13 \%$ for the wild type, $6 \%$ for the $h \operatorname{trA}$ S197A mutant, and $<5 \%$ for the $\Delta$ trA mutant. Therefore, once the bacteria have adhered to the host cells, $C$. jejuni needs HtrA protease activity for optimal internalization; the exact effect of 
the chaperone activity on internalization could not be assessed from these results, since no internalized $\Delta h t r A$ mutants could be recovered. Taken together, the results show that the chaperone activity of HtrA plays a significant role in attachment of $C$. jejuni to host cells. As HtrA is important for stress tolerance in C. jejuni $[18,31]$ we tested if the reduced binding of an $h t r A$ mutant to epithelial cells was simply the result of decreased survival. However, no loss of viability was observed for neither the wild type nor the htrA mutants in a control assay (Figure $1 C$ ), confirming that the number of CFU measured in the assay reflects the adherence and invasion capabilities of C. jejuni. This result indicates that the role of HtrA in host cell binding is more specific than improving the general stress response of $C$. jejuni, which is consistent with the observation that reduced host cell binding is not a general feature of $C$. jejuni mutants lacking key stress response proteins, such as ClpP and Lon [33]. Our results also show that the protease activity, and to some degree the chaperone activity, is required for optimal internalization of epithelial cells, although the effect of HtrA on this process is much smaller than the effect on adherence [31]. Reduced invasion by C. jejuni of epithelial cells is also observed in the absence of two cytoplasmic proteases, ClpP and Lon [33], indicating that proteolytic activity in general may be important during the process of host cell internalization.

To determine if the loss of HtrA also affects the ability of $C$. jejuni to be taken up by macrophages, cultured J774.1 mouse macrophages were infected with the wild type, the $\Delta h t r A$, and the $h t r A$ S197A mutant, and adherence and phagocytosis were quantified by a gentamicin protection assay. The number of adhered wild-type bacteria ranged from $0.03 \%-1.2 \%$ of the inoculum, while the number of phagocytosed wild-type bacteria ranged from $0.01 \%-0.19 \%$ of the inoculum. To assess the importance of HtrA in these processes the data for each $h t r A$ mutant was normalized to the wild type (Table 1 ). The complete lack of HtrA caused a mean reduction in adherence to macrophages of approximately three-fold, while adherence of the htrA S197A mutant was not different from that of the wild type (Table 1). Correspondingly, uptake by macrophages of the $\Delta h t r A$ mutant was reduced five-fold compared to the wild type, while

Table 1 Interaction of C. jejuni htrA mutants with macrophages

\begin{tabular}{ccc}
\hline Strain & Adherence $^{a}$ & Phagocytosis $^{\boldsymbol{a}}$ \\
\hline Wild type & 100 & 100 \\
\hline LB1281 ( (htrA) & $30 \pm 10$ & $21 \pm 9$ \\
\hline KB1025 (htrA S197A) & $96 \pm 33$ & $93 \pm 44$ \\
\hline
\end{tabular}

${ }^{a}$ Percentage of the value for the wild type \pm standard error. uptake of the htrA S197A mutant was not reduced (Table 1). From these data, we conclude that HtrA chaperone activity is important for macrophages to bind $C$. jejuni, and that HtrA does not affect phagocytosis by macrophages once the bacteria have been bound. In addition, the protease activity of HtrA is not important for the interaction of $C$. jejuni with macrophages.

Taken together, these results show that HtrA chaperone activity plays an important role in the attachment of $C$. jejuni to both epithelial cells and macrophages. We previously showed that the chaperone activity of HtrA is important for periplasmic protein homeostasis in $C$. jejuni under non-stress conditions [18], and we therefore speculate that HtrA of C. jejuni is involved in folding of periplasmic or outer membrane proteins. In E. coli and Shigella, HtrA acts as a chaperone that mediates proper folding and insertion of proteins into the outer membrane $[27,29]$. In C. jejuni, HtrA may therefore be essential for the function of one or several adherence factors, which may explain why lack of HtrA has a 5-10 times larger effect on adherence than lack of any single surface adhesin, such as CadF, CapA, JlpA and FlpA [11-14]. Interestingly, C. jejuni lacking PEB4, a homolog of the periplasmic chaperone SurA, adheres to epithelial cells 50-100 fold less efficiently than wild-type [34], emphasizing the importance of periplasmic chaperones for the adherence of $C$. jejuni to host cells.

\section{Surface properties and protein secretion of $C$. jejuni htrA mutants}

To pin-point the role of HtrA in the C. jejuni-cell interaction, we investigated if the surface protein pattern was altered in the $h t r A$ mutants. We compared the surface protein profiles using glycine-extracts from the wild type, the $\Delta h t r A$ mutant, and the $h t r A$ S197A mutant. This method allows extraction of several surface proteins [35-37] known to interact with eukaryotic cells $[10,38,39]$, but we did not identify proteins with an altered abundance in the $h t r A$ mutants compared to the wild type (Figure 2). However, lack of HtrA in bacteria may cause inactive proteins to appear on the bacterial surface, without affecting the amount of the particular protein. In Shigella, for example, loss of HtrA does not affect the amount of the virulence factor, IcsA, in the outer membrane, but instead causes IcsA to adopt an altered conformation with reduced activity [27]. Similarly, in the pathogenic E. coli O157:H7, it is proposed that the absence of $h t r A$ causes an autotransporter protein, involved in virulence, to misfold and wrongly insert into the outer membrane [40]. In addition to the adhesins mentioned above, the antigens PEB1 and PEB3 are important for adherence of $C$. jejuni to eukaryotic cells $[10,34]$ (B.W. Wren and R. Langdon, pers. comm.). Interestingly, PEB1 isolated from non-adherent $C$. jejuni 


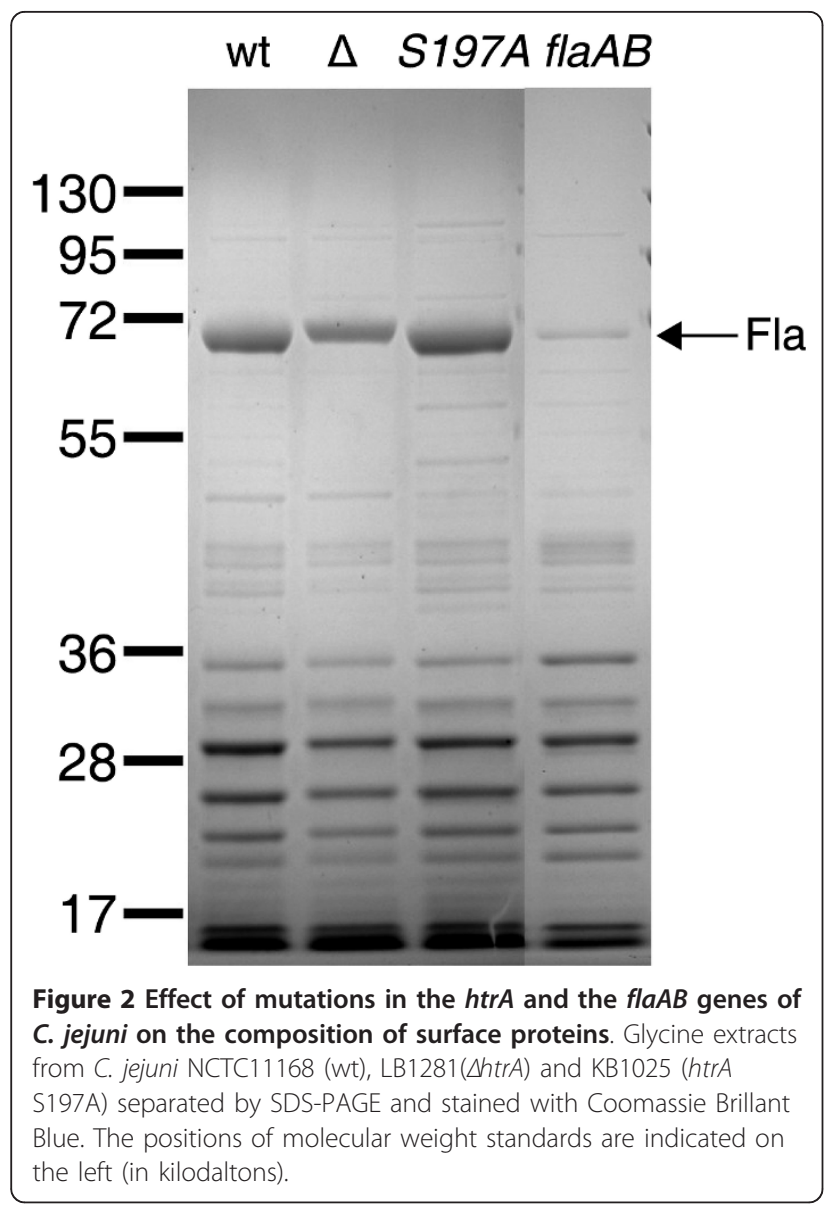

strains exists in slightly different isoforms compared to PEB1 isolated from adherent strains, indicating that small changes in PEB1 may affect adherence [10]. We speculate that the reduced adherence of the $h t r A$ mutants to epithelial cells is caused by misfolding or wrong localization of one or more adhesive proteins. Alternatively, HtrA may affect other periplasmic processes such as $N$ linked glycosylation of surface proteins like PEB3 and thus affect adherence to epithelial cells and macrophages [41]. Cells of the innate immune response, such as macrophages, identify infecting bacteria by recognition of a variety of molecular ligands on the bacterial surface, and it is possible that HtrA affects such ligands by similar mechanisms to those considered for the adhesins.

We observed a slight difference in mobility of FlaA in the $\triangle h t r A$ mutant compared to the wild type and the htrA S197A mutant, which correlated with our detection of a single nucleotide insertion in the homopolymeric tract (nucleotides 1,227,121 to 1,227,129 in reference genome NCTC11168) of gene cj1295 in the two latter strains, resulting in a premature stop codon. A similar polymorphism in cj1295 have previously been shown to cause a mobility shift of FlaA [42]. Bacterial motility, however, did not vary between the strains, nor did the appearance of the flagellum by electron microscopy [31]. Upon contact with human epithelial cells, C. jejuni secretes a set of proteins through the flagellum called Campylobacter invasive antigens (Cia), which have been shown to be important for invasion $[43,44]$. We tested if loss of htrA affects the secretion of Cia proteins by inducing Cia expression and secretion with sodium deoxycholate and bovine calf serum as described previously [45]. However, the protein pattern in the supernatant was not affected by lack of HtrA (Figure 3), and the reduced interaction with epithelial cells of $C$. jejuni mutants lacking $\mathrm{HtrA}$ is therefore not likely to be caused by impaired secretion of the these virulence factors.

\section{Conclusion}

It has long been known that HtrA is important for virulence of pathogenic bacteria, but not much attention has been given to the role of the individual activities of HtrA. This study demonstrates that particularly the chaperone activity of HtrA has a significant impact on the interaction between C. jejuni and host cells. Lack of HtrA reduced bacterial binding to epithelial cells 5-10 times more than lack of any known adhesin [11-14], suggesting a pleiotropic effect. Even though HtrA traditionally has been viewed as a stress response protein, our data indicate that HtrA has specific functions during infection that may be stress-independent. This

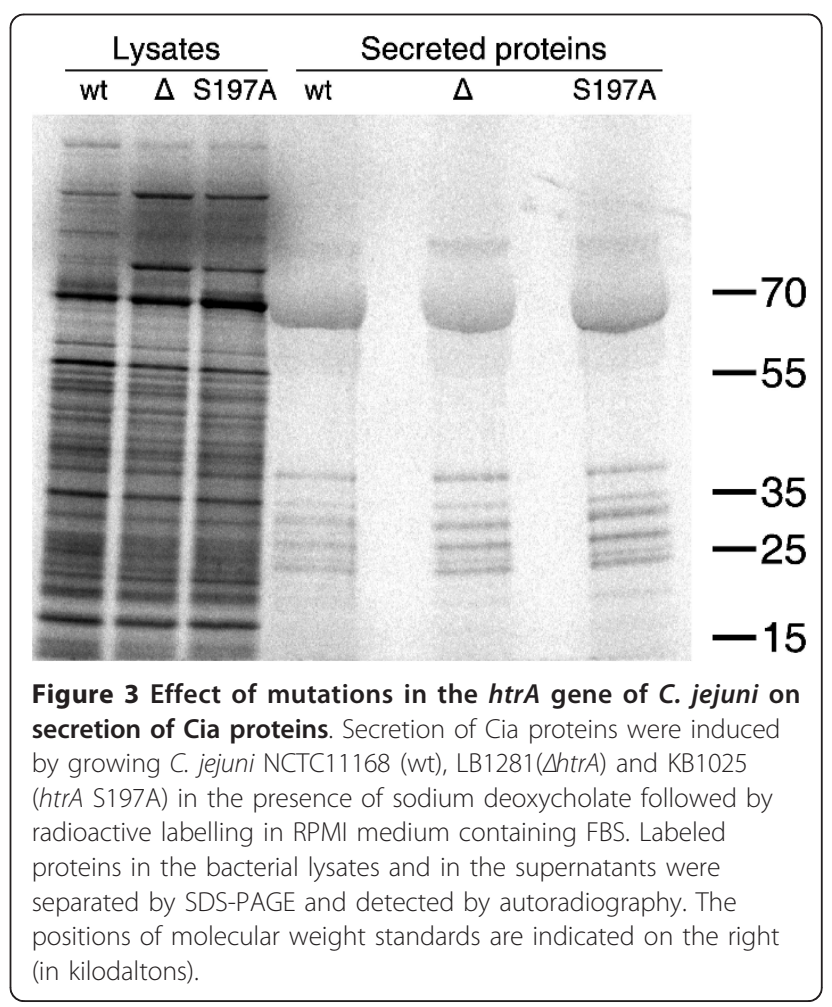


suggestion correlates with growing evidence from other bacteria showing that the chaperone activity of HtrA is involved in folding of virulence factors.

\section{Methods}

Bacterial strains and growth conditions

C. jejuni NCTC11168 (National Collection of Type Cultures), C. jejuni NCTC11168 htrA::cat (LB1281, [31]), C. jejuni NCTC11168 htrA S197A (KB1025, [18]), and C. jejuni NCTC11168 flaAB (CV1178) were routinely grown on blood agar base II (Oxoid) supplemented with $5 \%$ bovine blood, or in brain heart infusion (BHI) broth (Oxoid) at $37^{\circ} \mathrm{C}$ in a microaerobic environment $\left(6 \% \mathrm{O}_{2}\right.$, $6 \% \mathrm{CO}_{2}, 4 \% \mathrm{H}_{2}$, and $84 \% \mathrm{~N}_{2}$ ). CV1178 was constructed by natural transformation of $C$. jejuni NCTC11168 with chromosomal DNA from a C. jejuni 81116 flaAB mutant [46], followed by selection for kanamycin resistance.

\section{Cell cultures}

Stock cultures of INT 407 human embryonic intestinal epithelial cells were grown in minimal essential medium (MEM; Gibco) supplemented with $10 \%$ (vol/vol) fetal bovine serum (FBS; Gibco) and maintained at $37^{\circ} \mathrm{C}$ in a humidified, $5 \% \mathrm{CO}_{2}$ incubator. Stock cultures of J774.1 murine macrophage-like cells were grown in RPMI1640 (Gibco) supplemented with 10\% (vol/vol) FBS and maintained at $37^{\circ} \mathrm{C}$ in a humidified, $5 \% \mathrm{CO}_{2}$ incubator.

\section{Gentamicin protection assay}

Adherence and invasion/phagocytosis assays were performed with monolayers of INT407 epithelial cells or J774.1 macrophage cells growing in MEM (INT407) or RPMI (J774.1) supplemented with $10 \% \mathrm{FBS}$ at $37^{\circ} \mathrm{C}$ in a humidified microaerobic atmosphere containing 5\% $\mathrm{CO}_{2}$. Approximately $4 \times 10^{7}$ bacterial cells in MEM or RPMI were centrifuged at $400 \mathrm{rpm}$ onto a monolayer consisting of $4 \times 10^{5}$ host cells and incubated for $1 \mathrm{~h}$. The actual inocula were enumerated by plate count. To determine adherence, the monolayers were washed three times with $0.9 \% \mathrm{NaCl}$, and host cells were lysed by adding $0.1 \%$ Triton X-100. Adhered bacteria were enumerated by plate count. To determine invasion/ phagocytosis, the infected monolayers were incubated in MEM or RPMI containing $100 \mu \mathrm{g} \mathrm{ml}^{-1}$ gentamicin for 2 $\mathrm{h}$ at $37^{\circ} \mathrm{C}$ microaerobic-5\% $\mathrm{CO}_{2}$ atmosphere to kill extracellular bacteria. The monolayers were washed three times with $0.9 \% \mathrm{NaCl}$, host cells were lysed with $0.1 \%$ Triton $\mathrm{X}-100$, and internalized bacteria were enumerated by plate count. For the macrophage assay, the data from four individual experiments in duplicate was normalized to the values for the wild type, due to large variations between individual experiments. For the viability-control assay, a monolayer consisting of $4 \times 10^{5}$ INT407 cells was incubated in $1 \mathrm{ml}$ MEM supplemented with $10 \% \mathrm{FBS}$ at $37^{\circ} \mathrm{C}$ in $5 \% \mathrm{CO}_{2}$. After $1 \mathrm{~h}, 900 \mu \mathrm{l}$ medium was transferred to an empty well and approx. 4 $\times 10^{7}$ bacterial cells were added and incubated for $1 \mathrm{~h}$ at $37^{\circ} \mathrm{C}$ in a humidified microaerobic atmosphere containing $5 \% \mathrm{CO}_{2}$. Subsequently, Triton X-100 was added to $0.1 \%$ and bacteria enumerated by plate count.

\section{Protein secretion}

Secreted C. jejuni proteins were detected essentially as described in [45] and [43] with minor modifications. Briefly, C. jejuni NCTC11168, LB1281 and KB1025 were cultured $\mathrm{O} / \mathrm{N}$ in Mueller-Hinton $(\mathrm{MH})$ broth on $\mathrm{MH}$ agar containing $0.1 \%$ sodium deoxycholate (Sigma) to stimulate expression of the cia genes [45]. Bacteria were harvested in RPMI1640 without methionine (R7513, Sigma), pelleted at $8000 \times g$, and washed twice in RPMI1640. Six milliliters of a bacterial suspension containing approximately $10^{9} \mathrm{CFU}$ was labeled with $\mathrm{L}-{ }^{35} \mathrm{~S}$ methionine (Perkin Elmer Life Sciences) at a concentration of $50 \mu \mathrm{Ci} \mathrm{ml}{ }^{-1}$, and incorporation of ${ }^{35} \mathrm{~S}$ methionine was allowed for $30 \mathrm{~min}$ at $37^{\circ} \mathrm{C}$ under microaerobic conditions. Subsequently, the bacterial suspensions were incubated microaerobically at $37^{\circ} \mathrm{C}$ for $30 \mathrm{~min}$ with $128 \mathrm{\mu g} \mathrm{ml}^{-1}$ chloramphenicol to stop protein synthesis. The suspensions were then incubated with $1 \% \mathrm{FBS}$ (Gibco) for $30 \mathrm{~min}$ at $37^{\circ} \mathrm{C}$ under microaerobic conditions to stimulate protein secretion. Subsequently, the bacteria were harvested at $8000 \times g$, and the supernatants, containing the secreted proteins, were filtrated through a $0.2 \mu \mathrm{m}$ filter, and proteins were concentrated by adding five volumes of ice-cold 1 $\mathrm{mM} \mathrm{HCl}$-acetone followed by incubation $\mathrm{O} / \mathrm{N}$ at $-20^{\circ}$ C. The precipitated proteins were sedimented at $13,000 \times g$ and resuspended in water, followed by dialysis (6-8000 MWCO) to remove un-incorporated ${ }^{35} \mathrm{~S}$ methionine. The secreted proteins and whole-cell lysates were separated by SDS-PAGE and the dried gels were exposed to a phosphorimager screen (PerkinElmer) to detect labeled proteins.

\section{Surface proteins}

Surface associated proteins were extracted essentially as described by McCoy et al. [36]. Briefly, C. jejuni cells were harvested from blood agar plates, and the pellet was resuspended in $0.2 \mathrm{M}$ glycine- $\mathrm{HCl} \mathrm{pH} 2.2$ and incubated at room temperature for $10 \mathrm{~min}$ followed by removal of cells at $6,000 \times g$. Protein content in the extracts was quantified by densitometri of Amido Black stained proteins with BSA as standard, and equal amounts were separated by SDS-PAGE and stained with Coomassie Brillant Blue. 


\section{Acknowledgements}

Dr. Mark Reuter is thanked for providing chromosomal DNA from the $C$. jejuni flaAB mutant. We sincerely appreciate the expert technical assistance of Christel Galschiøt Buerholt and Jan Pedersen. This study was financially supported by the Faculty of Life Sciences, University of Copenhagen.

\section{Authors' contributions}

KTB participated in the design of the study, performed experiments, conducted data analysis, and drafted the manuscript. CSV and LB participated in the design of the study and edited the manuscript. All authors read and approved the final manuscript.

\section{Competing interests}

The authors declare that they have no competing interests.

Received: 24 August 2011 Accepted: 22 September 2011 Published: 22 September 2011

\section{References}

1. Allos BM: Campylobacter jejuni Infections: update on emerging issues and trends. Clin Infect Dis 2001, 32:1201-1206.

2. Young KT, Davis LM, Dirita VJ: Campylobacter jejuni: molecular biology and pathogenesis. NatRevMicrobiol 2007, 5:665-679.

3. van Spreeuwel JP, Duursma GC, Meijer CJ, Bax R, Rosekrans PC, Lindeman J: Campylobacter colitis: histological immunohistochemical and ultrastructural findings. Gut 1985, 26:945-951

4. Russell RG, O'Donnoghue M, Blake DC Jr, Zulty J, DeTolla LJ: Early colonic damage and invasion of Campylobacter jejuni in experimentally challenged infant Macaca mulatta. J Infect Dis 1993, 168:210-215.

5. Bacon DJ, Alm RA, Burr DH, Hu L, Kopecko DJ, Ewing CP, Trust TJ, Guerry P: Involvement of a plasmid in virulence of Campylobacter jejuni 81-176. Infect Immun 2000, 68:4384-4390.

6. Yao R, Burr DH, Guerry P: CheY-mediated modulation of Campylobacter jejuni virulence. Mol Microbiol 1997, 23:1021-1031.

7. Wassenaar TM, Engelskirchen M, Park S, Lastovica A: Differential uptake and killing potential of Campylobacter jejuni by human peripheral monocytes/macrophages. Med Microbiol Immunol 1997, 186:139-144.

8. Yao R, Burr DH, Doig P, Trust TJ, Niu H, Guerry P: Isolation of motile and non-motile insertional mutants of Campylobacter jejuni: the role of motility in adherence and invasion of eukaryotic cells. Mol Microbiol 1994, 14:883-893.

9. Bachtiar BM, Coloe PJ, Fry BN: Knockout mutagenesis of the kpsE gene of Campylobacter jejuni 81116 and its involvement in bacterium-host interactions. FEMS Immunol Med Microbiol 2007, 49:149-154.

10. Kervella M, Pages JM, Pei Z, Grollier G, Blaser MJ, Fauchere JL: Isolation and characterization of two Campylobacter glycine-extracted proteins that bind to HeLa cell membranes. Infect Immun 1993, 61:3440-3448.

11. Monteville MR, Yoon JE, Konkel ME: Maximal adherence and invasion of INT 407 cells by Campylobacter jejuni requires the CadF outermembrane protein and microfilament reorganization. Microbiology 2003, 149:153-165.

12. Konkel ME, Larson CL, Flanagan RC: Campylobacter jejuni FlpA binds fibronectin and is required for maximal host cell adherence. J Bacteriol 2010, 192:68-76.

13. Ashgar SS, Oldfield NJ, Wooldridge KG, Jones MA, Irving GJ, Turner DP, Ala'Aldeen DA: CapA, an autotransporter protein of Campylobacter jejuni, mediates association with human epithelial cells and colonization of the chicken gut. J Bacteriol 2007, 189:1856-1865.

14. Jin S, Joe A, Lynett J, Hani EK, Sherman P, Chan VL: JlpA, a novel surfaceexposed lipoprotein specific to Campylobacter jejuni, mediates adherence to host epithelial cells. Mol Microbiol 2001, 39:1225-1236.

15. Barnes $\mathbb{H}$, Bagnall MC, Browning DD, Thompson SA, Manning G, Newell DG: Gamma-glutamyl transpeptidase has a role in the persistent colonization of the avian gut by Campylobacter jejuni. Microb Pathog 2007, 43:198-207.

16. Novik V, Hofreuter D, Galan JE: Identification of Campylobacter jejuni genes involved in its interaction with epithelial cells. Infect Immun 2010, 78:3540-3553.

17. Spiess C, Beil A, Ehrmann M: A temperature-dependent switch from chaperone to protease in a widely conserved heat shock protein. Cell 1999, 97:339-347.
18. Bæk KT, Vegge CS, Skorko-Glonek J, Brondsted L: Different Contributions of HtrA Protease and Chaperone Activities to Campylobacter jejuni Stress Tolerance and Physiology. Appl Environ Microbiol 2011, 77:57-66.

19. Humphreys S, Stevenson A, Bacon A, Weinhardt AB, Roberts M: The alternative sigma factor, sigmaE, is critically important for the virulence of Salmonella typhimurium. Infect Immun 1999, 67:1560-1568.

20. Wilson RL, Brown LL, Kirkwood-watts D, Warren TK, Lund SA, King DS, Jones KF, Hruby DE: Listeria monocytogenes $10403 \mathrm{~S}$ HtrA Is Necessary for Resistance to Cellular Stress and Virulence. Microbiology 2006, 74:765-768.

21. Cortes G, de Astorza B, Benedi VJ, Alberti S: Role of the htrA gene in Klebsiella pneumoniae virulence. Infect Immun 2002, 70:4772-4776.

22. Li SR, Dorrell N, Everest PH, Dougan G, Wren BW: Construction and characterization of a Yersinia enterocolitica 0:8 high-temperature requirement (htrA) isogenic mutant. Infect Immun 1996, 64:2088-2094.

23. Laskowska E, Kuczynska-wisnik D, Skorko-Glonek J, Taylor A: Degradation by proteases Lon, Clp and HtrA, of Escherichia coli proteins aggregated in vivo by heat shock; HtrA protease action in vivo and in vitro. MolMicrobiol 1996, 22:555-571.

24. Skorko-Glonek J, Laskowska E, Sobiecka-Szkatula A, Lipinska B: Characterization of the chaperone-like activity of HtrA (DegP) protein from Escherichia coli under the conditions of heat shock. Arch Biochem Biophys 2007.

25. Strauch $\mathrm{KL}$, Johnson $\mathrm{K}$, Beckwith J: Characterization of degP, a gene required for proteolysis in the cell envelope and essential for growth of Escherichia coli at high temperature. J Bacterio/ 1989, 171:2689-2696.

26. Lewis C, Skovierova H, Rowley G, Rezuchova B, Homerova D, Stevenson A, Spencer J, Farn J, Kormanec J, Roberts M: Salmonella enterica Serovar Typhimurium HtrA: regulation of expression and role of the chaperone and protease activities during infection. Microbiology (Reading, England) 2009, 155:873-881.

27. Purdy GE, Fisher CR, Payne SM: IcsA surface presentation in Shigella flexneri requires the periplasmic chaperones DegP, Skp, and SurA. J Bacteriol 2007, 189:5566-5573.

28. Purdy GE, Hong M, Payne SM: Shigella flexneri DegP facilitates IcsA surface expression and is required for efficient intercellular spread. Infect Immun 2002, 70:6355-6364.

29. Sklar JG, Wu T, Kahne D, Silhavy TJ: Defining the roles of the periplasmic chaperones SurA, Skp, and DegP in Escherichia coli. Genes Dev 2007, 21:2473-2484.

30. Champion OL, Karlyshev AV, Senior NJ, Woodward M, La Ragione R, Howard SL, Wren BW, Titball RW: Insect infection model for Campylobacter jejuni reveals that O-methyl phosphoramidate has insecticidal activity. J Infect Dis 2010, 201:776-782.

31. Brøndsted $L$, Andersen MT, Parker $M$, Jorgensen $K$, Ingmer $H$ : The HtrA protease of Campylobacter jejuni is required for heat and oxygen tolerance and for optimal interaction with human epithelial cells. Appl Environ Microbiol 2005, 71:3205-3212.

32. Larson CL, Christensen JE, Pacheco SA, Minnich SA, Konkel ME: Campylobacter jejuni secretes proteins via the flagellar type III secretion system that contribute to host cell invasion and gastroenteritis. In Campylobacter. Edited by: Nachamkin I, Szymanski CM, Blaser MJ. Washington, DC: ASM Press; 2008:315331.

33. Cohn MT, Ingmer H, Mulholland F, Jorgensen K, Wells JM, Brondsted L: Contribution of conserved ATP-dependent proteases of Campylobacter jejuni to stress tolerance and virulence. Appl Environ Microbiol 2007, 73:7803-7813.

34. Asakura $H$, Yamasaki M, Yamamoto S, Igimi S: Deletion of peb4 gene impairs cell adhesion and biofilm formation in Campylobacter jejuni. FEMS Microbiol Lett 2007, 275:278-285.

35. Prokhorova TA, Nielsen PN, Petersen J, Kofoed T, Crawford JS, Morsczeck C, Boysen A, Schrotz-King P: Novel surface polypeptides of Campylobacter jejuni as traveller's diarrhoea vaccine candidates discovered by proteomics. Vaccine 2006, 24:6446-6455.

36. McCoy EC, Doyle D, Burda K, Corbeil LB, Winter AJ: Superficial antigens of Campylobacter (Vibrio) fetus: characterization of antiphagocytic component. Infect Immun 1975, 11:517-525.

37. Logan SM, Trust TJ: Molecular identification of surface protein antigens of Campylobacter jejuni. Infect Immun 1983, 42:675-682. 
38. de Melo MA, Pechere JC: Identification of Campylobacter jejuni surface proteins that bind to Eucaryotic cells in vitro. Infect Immun 1990, 58:1749-1756.

39. Pei Z, Burucoa C, Grignon B, Baqar S, Huang XZ, Kopecko DJ, Bourgeois AL, Fauchere JL, Blaser MJ: Mutation in the peb1A locus of Campylobacter jejuni reduces interactions with epithelial cells and intestinal colonization of mice. Infect Immun 1998, 66:938-943.

40. Ruiz-Perez F, Henderson IR, Leyton DL, Rossiter AE, Zhang Y, Nataro JP: Roles of periplasmic chaperone proteins in the biogenesis of serine protease autotransporters of Enterobacteriaceae. J Bacteriol 2009, 191:6571-6583.

41. Szymanski CM, Burr DH, Guerry P: Campylobacter protein glycosylation affects host cell interactions. Infect Immun 2002, 70:2242-2244.

42. Hitchen P, Brzostek J, Panico M, Butler JA, Morris HR, Dell A, Linton D: Modification of the Campylobacter jejuni flagellin glycan by the product of the Cj1295 homopolymeric-tract-containing gene. Microbiology 2010, 156:1953-1962.

43. Konkel ME, Cieplak W Jr: Altered synthetic response of Campylobacter jejuni to cocultivation with human epithelial cells is associated with enhanced internalization. Infect/mmun 1992, 60:4945-4949.

44. Konkel ME, Kim BJ, Rivera-amill V, Garvis SG: Bacterial secreted proteins are required for the internaliztion of Campylobacter jejuni into cultured mammalian cells. MolMicrobiol 1999, 32:691-701.

45. Malik-Kale P, Parker CT, Konkel ME: Culture of Campylobacter jejuni with sodium deoxycholate induces virulence gene expression. J Bacteriol 2008, 190:2286-2297.

46. Wassenaar TM, Bleumink-Pluym NM, van der Zeijst BA: Inactivation of Campylobacter jejuni flagellin genes by homologous recombination demonstrates that flaA but not flaB is required for invasion. EMBO J 1991, 10:2055-2061.

doi:10.1186/1757-4749-3-13

Cite this article as: Bæk et al:: $\mathrm{HtrA}$ chaperone activity contributes to host cell binding in Campylobacter jejuni. Gut Pathogens 2011 3:13.

\section{Submit your next manuscript to BioMed Central and take full advantage of:}

- Convenient online submission

- Thorough peer review

- No space constraints or color figure charges

- Immediate publication on acceptance

- Inclusion in PubMed, CAS, Scopus and Google Scholar

- Research which is freely available for redistribution

Submit your manuscript at www.biomedcentral.com/submit 